\title{
Review Article \\ Pharmacokinetic Interactions of Herbs with Cytochrome P450 and P-Glycoprotein
}

\author{
Hyun-Jong Cho' ${ }^{1}$ and In-Soo Yoon ${ }^{2}$ \\ ${ }^{1}$ College of Pharmacy, Kangwon National University, Chuncheon 200-701, Republic of Korea \\ ${ }^{2}$ College of Pharmacy and Natural Medicine Research Institute, Mokpo National University, 1666 Youngsan-ro, \\ Muan-gun, Jeonnam 534-729, Republic of Korea
}

Correspondence should be addressed to In-Soo Yoon; yooninsu99@naver.com

Received 31 July 2014; Revised 20 December 2014; Accepted 20 December 2014

Academic Editor: Angelo A. Izzo

Copyright (c) 2015 H.-J. Cho and I.-S. Yoon. This is an open access article distributed under the Creative Commons Attribution License, which permits unrestricted use, distribution, and reproduction in any medium, provided the original work is properly cited.

\begin{abstract}
The concurrent use of drugs and herbal products is becoming increasingly prevalent over the last decade. Several herbal products have been known to modulate cytochrome P450 (CYP) enzymes and P-glycoprotein (P-gp) which are recognized as representative drug metabolizing enzymes and drug transporter, respectively. Thus, a summary of knowledge on the modulation of CYP and P-gp by commonly used herbs can provide robust fundamentals for optimizing CYP and/or P-gp substrate drug-based therapy. Herein, we review ten popular medicinal and/or dietary herbs as perpetrators of CYP- and P-gp-mediated pharmacokinetic herb-drug interactions. The main focus is placed on previous works on the ability of herbal extracts and their phytochemicals to modulate the expression and function of CYP and P-gp in several in vitro and in vivo animal and human systems.
\end{abstract}

\section{Introduction}

In the last decade, a number of herbal products have attracted growing interest as a complementary and alternative medicine for the prevention and treatment of various diseases [1]. Recent surveys have reported that the prevalence of herbal medicine use is approximately $20 \%$ and the concurrent use of herbal medicine occurs in $20-30 \%$ of prescription drug users in the United States [2-4]. Herbal products have been generally considered as natural and safe. However, some of their constituents can modulate various xenobiotic metabolism and transport systems which play a significant role in the absorption and disposition of prescription drugs. Therefore, drug metabolizing enzymes and drug transporters-mediated herb-drug interactions can occur frequently in drug-and/or herb-based therapies $[1,5]$.

Phase I metabolism generally results in the introduction of a hydrophilic functional group into molecules or the unveiling of new functional groups of molecules. It includes various reaction types such as oxidation, reduction, and hydrolysis. Cytochrome P450 (CYP) monooxygenase is a superfamily of hemoproteins responsible for the phase I metabolism of various xenobiotics and some endogenous substances such as steroids [6]. Although CYP is ubiquitously expressed in a number of organs, most of drug metabolizing CYP isoforms are expressed at the highest level in the liver [7]. Approximately $70-80 \%$ of all currently prescribed drugs are metabolized by the CYP system [8]. P-glycoprotein (Pgp), also known as multidrug resistance protein, is an ATPdependent efflux pump with broad substrate specificity $[9$, 10]. P-gp is highly expressed in the apical (luminal) membrane of intestinal epithelium, hepatocytes, kidney proximal tubule epithelium, and brain capillary endothelium, where it pumps a variety of xenobiotics into the intestinal lumen, bile duct, renal tubule, and brain capillary, respectively [11, 12]. It plays an important role in the intestinal absorption, distribution to the central nervous system, and biliary/urinary excretion of drugs [13]. Therefore, the inhibition or induction of CYP and/or P-gp by concurrent herbs may result in pharmacokinetic interactions potentially leading to therapeutic failure [14]. On the other hand, the herbal modulation of their expression and/or activity could be a useful strategy to improve the efficacy and safety of CYP and/or P-gp substrate drugs [14]. 
Here, this paper reviews some of the commonly used medicinal and/or dietary herbs as perpetrators of CYP- and $\mathrm{P}$-gp-mediated pharmacokinetic drug interactions. The main focus is placed on a current understanding on the effect of selected herbs and their phytochemicals on the expression and activity of CYP and P-gp in several in vitro and in vivo animal and human systems. St. John's Wort and grapefruit are not addressed in this paper, because they are welldocumented as CYP and P-gp modulators in many previous reviews.

\section{Herbal Modulations of CYP and P-gp}

2.1. Ginkgo biloba. Ginkgo biloba (ginkgo), also called as maidenhair tree, is 190 million years old and unique species of dioecious tree with no closing living relatives $[1,15]$. The extracts of the ginkgo leaves have been widely used as a phytomedicine in Europe and as a dietary supplement in the United States [6]. The main pharmacologically active phytochemicals of the ginkgo extracts include flavonoid glycosides (e.g., quercetin, kaempferol, and isorhamnetin) and unique terpene lactones (ginkgolides; Figure 1) [6]. Ginkgolides are potent inhibitors of platelet activating factor, and ginkgo extracts are used for the treatment of cerebrovascular dysfunctions, dementia, memory impairment, and peripheral vascular disorders $[16,17]$. The recommended dose of ginkgo is $120-240 \mathrm{mg} /$ day for the treatment of dementia and memory impairment [1].

The effect of ginkgo and its main active components on the expression and activity of CYP and P-gp is listed in Table 1 . In rats, the mRNA levels of CYP2B1/2 and 3A1/2 were significantly increased in rats treated with ginkgo extract during 4 weeks, while those of CYP1A1/2, 2C11, 2E1, and 4A1 were not significantly changed [18]. However, in another study, the in vivo activity of CYP1A2 was significantly increased in rats, which is not consistent with the mRNA results [19]. In human, the in vivo activity of CYP3A4 was increased, while the in vitro activities of CYP1A2, 2C9, and 2E1 were decreased by ginkgo extract $[20,21]$. The in vitro or in vivo activity of human P-gp was significantly reduced by ginkgo extract $[22,23]$. The activity of CYP1A2 and 2C9 was not significantly changed by ginkgolides, while that of CYP3A4 was increased by ginkgolide A via pregnane $\mathrm{X}$ receptor [24, 25].

\subsection{Allium sativum and Allium cepa. Allium sativum (garlic)} is a widely used medicinal and dietary herb which has antioxidant, antibacterial, hepatoprotective, hypolipidemic, antihypertensive, antiplatelet, procirculatory, antidiabetic, anticancer, and immunoenhancing efficacy [1, 26]. Garlic bulbs and cloves are mainly used for pharmaceutical products in the form of powder, oily preparation, or aqueous alcoholic extract $[1,27]$. The main pharmacologically active phytochemicals of garlic include alliin (Figure 2(a)) and allicin (Figure 2(b)), diallyl disulphide, and diallyl sulphide [28]. Alliin is metabolized to allicin, and it is subsequently degraded to various organosulfur compounds including diallyl disulphide and diallyl sulphide which are believed to be mainly responsible for the beneficial biological effects of garlic [29]. The recommended dose of fresh garlic is about

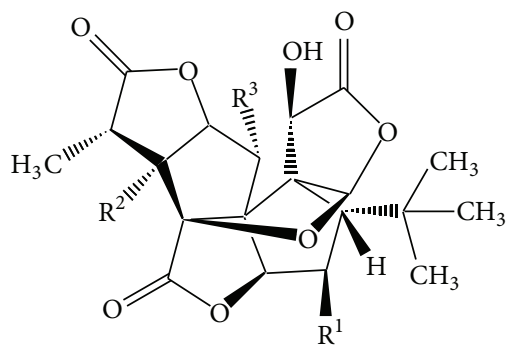

$\begin{array}{lccc} & \mathrm{R}^{1} & \mathrm{R}^{2} & \mathrm{R}^{3} \\ \text { Ginkgolide A } & \mathrm{H} & \mathrm{OH} & \mathrm{H} \\ \text { Ginkgolide B } & \mathrm{H} & \mathrm{OH} & \mathrm{OH} \\ \text { Ginkgolide C } & \mathrm{OH} & \mathrm{OH} & \mathrm{OH} \\ \text { Ginkgolide J } & \mathrm{OH} & \mathrm{OH} & \mathrm{H} \\ \text { Ginkgolide M } & \mathrm{OH} & \mathrm{H} & \mathrm{OH}\end{array}$

FIGURE 1: Chemical structures of ginkgolides.<smiles>C=CCS(=O)C[C@H](N)C(=O)O</smiles>

(a)

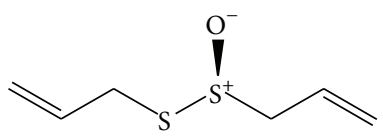

(b)

Figure 2: Chemical structures of alliin (a) and allicin (b).

$4 \mathrm{~g} /$ day which is equivalent to about $8 \mathrm{mg}$ garlic oil or $600-$ $900 \mathrm{mg}$ garlic powder daily standardized to $1.3 \%$ alliin content [1].

The effect of garlic and its main active components on the expression and activity of CYP and P-gp is listed in Table 2. In mouse, the administration of garlic juice for 8 days induced the protein expression of CYP1A2 and 2E1 [30]. Garlic extract inhibited in vitro CYP2C9* $1,2 \mathrm{C} 19,3 \mathrm{~A} 4$, 3A5, and 3A7 activity, while it did not affect the CYP2D6 activity, and increased CYP2C9* 2 activity in recombinant human CYP isozyme system [31]. A few divergent results on the modulation of P-gp by garlic have been reported as follows: a previous study reported the inhibitory effect of garlic extract on P-gp activity [31]; another study suggested the inductive effect of garlic extract on intestinal P-gp activity $[32,33]$; P-gp activity in human CD4 cells was not affected by garlic extract without allicin [34]. Diallyl disulfide induced in vivo CYP2B1/2 activity in rats and inhibited in vitro CYP2E1 activity in recombinant rat and human CYP isozyme system $[35,36]$. Allicin also inhibited in vitro CYP1A2 activity in recombinant human CYP isozyme system [36].

Allium cepa (onion) is a daily diet and has been used as a medicinal and dietary supplement for the treatment of 
TABLE 1: The modulation of CYP and P-gp by ginkgo.

\begin{tabular}{|c|c|c|c|c|c|}
\hline Compound type & Species & System & CYP & P-gp & Ref. \\
\hline Extract & Rat & $\begin{array}{l}\text { In vivo } \\
\text { mRNA }\end{array}$ & $\begin{array}{l}\text { CYP1A1/2 }(\leftrightarrow) \\
\text { CYP2B1/2 }(\uparrow) \\
\text { CYP2C11 }(\leftrightarrow) \\
\text { CYP2E1 }(\leftrightarrow) \\
\text { CYP3A1/2 }(\uparrow) \\
\text { CYP4A1 }(\leftrightarrow)\end{array}$ & & {$[18]$} \\
\hline Extract & Rat & $\begin{array}{l}\text { In vivo } \\
\text { Activity }\end{array}$ & CYP1A2 $(\uparrow)$ & & [19] \\
\hline Extract & Human & $\begin{array}{l}\text { In vitro } \\
\text { Activity }\end{array}$ & $\begin{array}{l}\text { CYP1A2 }(\downarrow) \\
\text { CYP2C9 }(\downarrow) \\
\text { CYP2E1 }(\downarrow)\end{array}$ & & {$[20]$} \\
\hline Extract & Human & $\begin{array}{l}\text { In vivo } \\
\text { Activity }\end{array}$ & CYP3A4 $(\uparrow)$ & & {$[21]$} \\
\hline Extract & Human & $\begin{array}{c}\text { In vitro/in vivo } \\
\text { Activity }\end{array}$ & & P-gp $(\downarrow)$ & {$[22,23]$} \\
\hline Ginkgolides & Human & $\begin{array}{l}\text { In vitro } \\
\text { Activity }\end{array}$ & $\begin{array}{l}\text { CYP1A2 }(\leftrightarrow) \\
\text { CYP2C9 }(\leftrightarrow)\end{array}$ & & {$[24]$} \\
\hline Ginkgolide A & Human & $\begin{array}{l}\text { In vitro } \\
\text { Activity }\end{array}$ & CYP3A4 $(\uparrow)$ & & {$[25]$} \\
\hline
\end{tabular}

TABLE 2: The modulation of CYP and P-gp by garlic.

\begin{tabular}{|c|c|c|c|c|c|}
\hline Compound type & Species & System & CYP & P-gp & Ref. \\
\hline Extract & Mouse & $\begin{array}{l}\text { In vivo } \\
\text { Protein }\end{array}$ & $\begin{array}{l}\text { CYP1A2 }(\uparrow) \\
\text { CYP2E1 }(\uparrow)\end{array}$ & & {$[30]$} \\
\hline Extract & Human & $\begin{array}{l}\text { In vitro } \\
\text { Activity }\end{array}$ & $\begin{array}{c}\text { CYP2C9* } 1(\downarrow) \text { CYP2C9* }^{*}(\uparrow) \\
\text { CYP2C19 }(\downarrow) \\
\text { CYP2D6 }(\leftrightarrow) \\
\text { CYP3A4 }(\downarrow) \\
\text { CYP3A5 }(\downarrow) \\
\text { CYP3A7 }(\downarrow) \\
\end{array}$ & & {$[31]$} \\
\hline Extract & Human & $\begin{array}{l}\text { In vitro } \\
\text { Activity }\end{array}$ & & P-gp $(\downarrow)$ & {$[31]$} \\
\hline Extract & Human & $\begin{array}{l}\text { In vivo } \\
\text { Activity }\end{array}$ & & P-gp $(\uparrow)$ & {$[32,33]$} \\
\hline Extract w/o allicin & Human & $\begin{array}{l}\text { In vitro } \\
\text { Activity }\end{array}$ & & P-gp $(\leftrightarrow)$ & {$[34]$} \\
\hline Diallyl disulfide & Rat & $\begin{array}{c}\text { In vitro/in vivo } \\
\text { Activity }\end{array}$ & $\begin{array}{c}\text { CYP2B1/2 }(\uparrow) \\
\text { CYP2E1 }(\downarrow)\end{array}$ & & {$[35]$} \\
\hline Diallyl disulfide & Human & $\begin{array}{l}\text { In vitro } \\
\text { Activity }\end{array}$ & 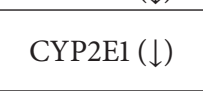 & & {$[36]$} \\
\hline Allicin & Human & $\begin{array}{l}\text { In vitro } \\
\text { Activity }\end{array}$ & CYP1A2 $(\downarrow)$ & & {$[36]$} \\
\hline
\end{tabular}

hypertension and hyperlipidemia [37]. Onion extract possesses several pharmacological activities including antihypertensive, hypolipidemic, antithrombotic, antioxidant, antibacterial, and anticancer effects $[38,39]$. The main pharmacological component of onion is known to be quercetin [37]. Onion extract did not significantly change P-gp-mediated efflux of rhodamine-123 in the everted rat gut sac system [37]. However, quercetin inhibited P-gp-mediated efflux of ritonavir in Caco-2 cells and human CYP3A4 activity in the
Vivid assay kit system, while prolonged exposure of quercetin increased the mRNA expression of both P-gp and CYP3A4 in Caco-2 cells [40].

2.3. Camellia sinensis. Camellia sinensis (green tea) is used worldwide as a medicinal and dietary herb. Its leaves are consumed as a beverage, and its purified extract has been approved as a botanical drug by United States Food and Drug Administration (US FDA) [33]. A typical green tea beverage 
TABle 3: The modulation of CYP and P-gp by green tea.

\begin{tabular}{|c|c|c|c|c|c|}
\hline Compound type & Species & System & CYP & P-gp & Ref. \\
\hline Extract & Rat & $\begin{array}{l}\text { In vivo } \\
\text { Activity }\end{array}$ & $\begin{array}{l}\text { CYP1A }(\uparrow) \\
\text { CYP2B }(\uparrow) \\
\text { CYP3A }(\uparrow)\end{array}$ & & {$[41-43]$} \\
\hline Extract & Human & $\begin{array}{l}\text { In vitro } \\
\text { Activity }\end{array}$ & $\begin{array}{l}\text { CYP2C9 }(\downarrow) \\
\text { CYP2D6 }(\downarrow) \\
\text { CYP3A4 }(\downarrow) \\
\end{array}$ & & {$[43]$} \\
\hline Extract & Human & $\begin{array}{c}\text { In vitro } \\
\text { mRNA/protein }\end{array}$ & $\begin{array}{l}\text { CYP1A1 }(\uparrow) \\
\text { CYP1A2 }(\uparrow)\end{array}$ & & {$[44]$} \\
\hline EGCG & Human & $\begin{array}{l}\text { In vitro } \\
\text { Activity }\end{array}$ & $\begin{array}{l}\text { CYP1A2 }(\downarrow) \\
\text { CYP3A4 }(\downarrow)\end{array}$ & & {$[44]$} \\
\hline Catechins & Human & $\begin{array}{l}\text { In vitro } \\
\text { Activity }\end{array}$ & & P-gp $(\downarrow)$ & {$[45]$} \\
\hline EGCG & Human & $\begin{array}{l}\text { In vitro } \\
\text { Activity }\end{array}$ & & P-gp $(\downarrow)$ & {$[46]$} \\
\hline
\end{tabular}

contains 30-42\% dry-weight catechins which are the main pharmacologically active phytochemicals of green tea [47]. Epigallocatechin gallate (EGCG) is known as the most abundant catechin of green tea [10]. Numerous studies reported that green tea has anticancer, anti-inflammatory, chemopreventive, antimetastatic, and vasculoprotective properties [4850]. The effect of green tea and its main active components on the expression and activity of CYP and P-gp is listed in Table 3. In rats, the administration of green tea extract increased the in vivo activity of CYP1A, 2B, and 3A [4143]. In human, green tea extract inhibited CYP2C9, 2D6, and 3A4 activities in human liver microsomes [43], while it induced the mRNA and protein expression of CYP1A2 in LS180 cells and CYP1A1/2 in Caco-2 cells [44]. Moreover, EGCG inhibited CYP1A2 and 3A4 activity in the same cell lines [44]. Green tea polyphenols including EGCG also inhibited P-gpmediated efflux activity in multidrug-resistant $\mathrm{CH}(\mathrm{R}) \mathrm{C} 5$ [45] and KB-A1 cells [46].

2.4. Glycyrrhiza glabra. The root of Glycyrrhiza glabra (licorice) is used as a herbal medicine for the treatment of peptic ulcer and cough and as a food additive for sweetening candies, beverages, and chewing gums $[6,51]$. The main phytochemicals of licorice include glycyrrhizin (Figure 3(a)), liquiritigenin, coumarins, stilbenoids, fatty acids, phenols, and sterols [52]. Glycyrrhizin is metabolized by intestinal flora into its pharmacologically active form, glycyrrhetinic acid (Figure 3(b)). Licorice is known to have antimalarial, ulcer-healing, immunosuppressive, antihepatotoxic, antianemic, and anti-inflammatory properties $[6,53]$. In mice and rats, multiple oral doses of licorice extract during 4 or 10 days induced the mRNA and protein expression of CYP3A and activity of CYP1A2, 2B1, and 3A [54]. Concurrent administration of glycyrrhizin altered the oral pharmacokinetics of midazolam in healthy male subjects possibly by a modest induction of CYP3A4 [55]. Moreover, glycyrrhetinic acid inhibited P-gp-mediated efflux of daunorubicin in P-gpoverexpressing KB-C2 cells [56].
2.5. Zingiber officinale. Zingiber officinale (ginger) has been widely used for the treatment of nausea and dyspepsia [57]. It acts as an agonist of cholinergic receptors expressed in the gastrointestinal tract, which is believed to be a mechanism of its prokinetic effect [58]. Moreover, ginger has several pharmacologic activities such as antiplatelets, antioxidant, antitumor, antivirus, antihepatotoxicity, and anti-inflammation [59]. The main pharmacologic component of ginger is gingerols (Figure 4(a)) which have a pungent flavor [60]. Ginger extract inhibited CYP2C9 and 3A4 activities in recombinant human CYP isozyme system [61] and CYP2C19 activity in human liver microsomes [62]. 6-gingerol inhibited P-gpmediated efflux of daunorubicin and rhodamine-123 in KBC2 cells [63], while it did not significantly change the in vitro activity of human CYP1A2, 2C9, 2D6, and 3A4 [64].

2.6. Piper nigrum. Piper nigrum (pepper) is widely used as a food ingredient with spicy taste [28]. The main active component of pepper is alkaloid piperine (Figure 4(b)) which is also used as a dietary supplement [65]. Piperine has several beneficial properties including antidiarrhoeal, chemopreventive, anti-inflammatory, antioxidant, and immunoenhancing activities [66-70]. Moreover, piperine may act as a bioavailability enhancer by inhibiting gastric emptying and gastrointestinal transit [71]. Bioperine is a commercial herbal product containing a minimum of $98 \%$ pure alkaloid piperine extracted from the fruits of black pepper [72]. It enhanced the oral bioavailability of coenzyme Q10 after single or multiple (14 and 21 days) dosing in twelve healthy adult male subjects [73]. The protein expression of hepatic CYP1A and 2B increased, while that of CYP2E1 decreased following multiple intraperitoneal injections of piperine in rats [74]. Piperine inhibited CYP3A4-mediated metabolism of verapamil in human liver microsomes and P-gp-mediated efflux of digoxin and cyclosporine in Caco-2 cells [75].

2.7. Rosmarinus officinalis. Rosmarinus officinalis (rosemary) has been used as a dietary herb for beverage, flavouring 


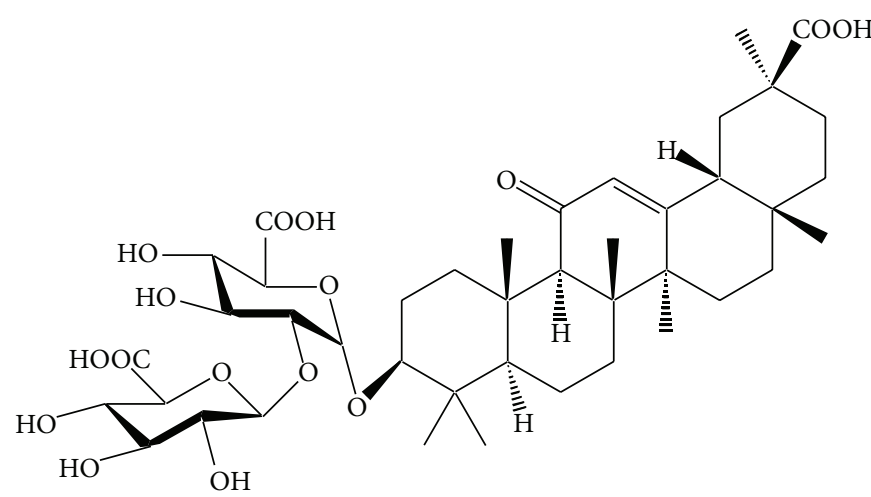

(a)

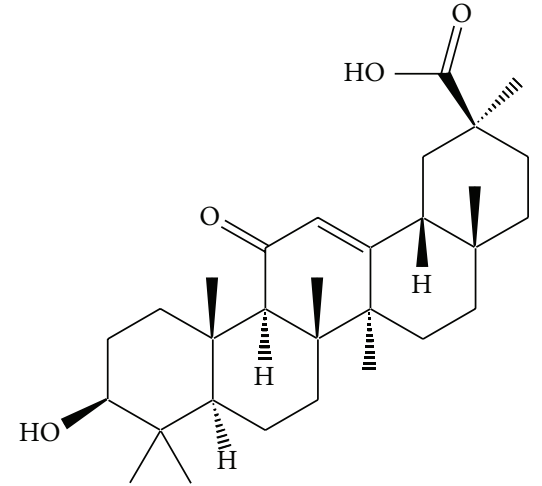

(b)

FIGURE 3: Chemical structures of glycyrrhizin (a) and glycyrrhetic acid (b).<smiles>CC[C@H](O)CC(=O)CCc1ccc(O)c(OC)c1</smiles>

(a)<smiles>O=C(/C=C/C=C/c1ccc2c(c1)OCO2)N1CCCCC1</smiles>

(b)

FIGURE 4: Chemical structures of gingerols (a) and piperine (b).<smiles>O=C(/C=C/c1ccc(O)c(O)c1)O[C@@H](Cc1ccc(O)c(O)c1)C(=O)O</smiles>

(a)<smiles>COc1cc(/C=C/C(=O)/C=C(O)/C=C/c2ccc(O)c(OC)c2)ccc1O</smiles>

(b)

FIgURE 5: Chemical structures of rosmarinic acid (a) and curcumin (b).

food, and cosmetics and as a medicinal herb for stimulant, antirheumatic, diuretic, analgesic, antiepileptic, and cancer prevention [76]. The main active component of rosemary is rosmarinic acid (Figure 5(a)) [77]. The effect of rosemary and its main active component on the expression and activity of CYP and P-gp is listed in Table 4. Oral treatment with rosemary extract increased the protein expression of hepatic CYP2B1/2, while it did not change hepatic CYP1A1/2 in rats [78]. Moreover, rosemary extract inhibited P-gp-mediated efflux of doxorubicin and vinblastine in P-gp-overexpressing MCF-7 cells [79]. Rosmarinic acid induced the in vitro activity of CYP1A, 2B, and 3A in rat HepG2/C3A and MH1C1 cells [80]. However, it inhibited human recombinant CYP3A4 activity, but not CYP2C9 and 2D6 activities [81]. It reduced the mRNA and protein expression of P-gp and also inhibited P-gp-mediated efflux of doxorubicin and rhodamine 123 in SGC7901/Adr cells [82].
2.8. Curcuma longa. Curcuma longa (turmeric) has been widely used as food additives, cosmetics, and medical preparations for stomach upset, inflammation, skin wound, and tumor $[10,88]$. The main active component of turmeric is curcumin (Figure 5(b)). Curcumin has antioxidant, anti-inflammatory, hypolipidemic, and anticancer activities, which may be attributed to its inhibitory effect on several cell signal transduction pathways [89-92]. In rats, the protein expression of intestinal CYP3A and P-gp was significantly reduced by treatment with curcumin at a dose of $60 \mathrm{mg} / \mathrm{kg} / \mathrm{day}$ for 4 days [93]. Moreover, the protein expression of P-gp in primary cultured rat hepatocytes was reduced following $72 \mathrm{~h}$ cultures with curcumin [94]. Curcumin inhibited the activity of CYP1A1, 1A2, and $2 \mathrm{~B} 1$ in rat liver microsomes [95]. In Caco-2 cells, curcumin reduced the mRNA expression and activity of P-gp, while turmeric extract increased these parameters [96]. However, 
TABLE 4: The modulation of CYP and P-gp by rosemary.

\begin{tabular}{|c|c|c|c|c|c|}
\hline Compound type & Species & System & CYP & P-gp & Ref. \\
\hline Extract & Rat & $\begin{array}{l}\text { In vivo } \\
\text { Protein }\end{array}$ & $\begin{array}{l}\text { CYP1A1/2 }(\leftrightarrow) \\
\text { CYP2B1/2 }(\uparrow)\end{array}$ & & {$[78]$} \\
\hline Extract & Human & $\begin{array}{l}\text { In vitro } \\
\text { Activity }\end{array}$ & & P-gp $(\downarrow)$ & [79] \\
\hline Rosmarinic acid & Rat & $\begin{array}{l}\text { In vitro } \\
\text { Activity }\end{array}$ & $\begin{array}{l}\text { CYP1A }(\uparrow) \\
\text { CYP2B }(\uparrow) \\
\text { CYP3A }(\uparrow)\end{array}$ & & {$[80]$} \\
\hline Rosmarinic acid & Human & $\begin{array}{l}\text { In vitro } \\
\text { Activity }\end{array}$ & $\begin{array}{c}\text { CYP2C9 }(\leftrightarrow) \\
\text { CYP2D6 }(\leftrightarrow) \\
\text { CYP3A4 }(\downarrow)\end{array}$ & & {$[81]$} \\
\hline Rosmarinic acid & Human & $\begin{array}{c}\text { In vitro } \\
\text { mRNA/protein } \\
\text { Activity }\end{array}$ & & P-gp $(\downarrow)$ & {$[82]$} \\
\hline
\end{tabular}

TABLE 5: The modulation of CYP and P-gp by ginseng.

\begin{tabular}{|c|c|c|c|c|c|}
\hline Compound type & Species & System & CYP & P-gp & Ref. \\
\hline Extract & Rat & $\begin{array}{l}\text { In vitro } \\
\text { Activity }\end{array}$ & $\begin{array}{c}\text { CYP1A1/2 }(\downarrow) \\
\text { CYP1B1 }(\downarrow) \\
\text { CYP2E1 }(\downarrow)\end{array}$ & & [83] \\
\hline Extract & Rat & $\begin{array}{l}\text { In vitro } \\
\text { mRNA }\end{array}$ & $\begin{array}{r}\text { CYP1A2 }(\leftrightarrow) \\
\text { CYP2B1 }(\leftrightarrow) \\
\text { CYP3A23 }(\leftrightarrow)\end{array}$ & & [84] \\
\hline Extract & Human & $\begin{array}{l}\text { In vitro } \\
\text { Activity }\end{array}$ & $\begin{array}{l}\text { CYP1A1 }(\downarrow) \\
\text { CYP1A2 }(\downarrow) \\
\text { CYP1B1 }(\downarrow)\end{array}$ & & [85] \\
\hline Ginsenoside Rd & Human & $\begin{array}{l}\text { In vitro } \\
\text { Activity }\end{array}$ & $\begin{array}{l}\text { CYP2C9 }(\downarrow) \\
\text { CYP2C19 }(\downarrow) \\
\text { CYP2D6 }(\downarrow) \\
\text { CYP3A4 }(\downarrow) \\
\end{array}$ & & [86] \\
\hline Ginsenoside Rc, Rf & Human & $\begin{array}{l}\text { In vitro } \\
\text { Activity }\end{array}$ & $\begin{array}{l}\text { CYP2C9 }(\uparrow) \\
\text { CYP3A4 }(\uparrow)\end{array}$ & & [86] \\
\hline Ginsenoside Rg3 & Human & $\begin{array}{l}\text { In vitro } \\
\text { Activity }\end{array}$ & & P-gp $(\downarrow)$ & [87] \\
\hline
\end{tabular}

both curcumin and turmeric extract reduced the protein expression and activity of CYP3A4 without affecting its mRNA expression in dihydroxyvitamin D3-treated Caco-2 cells [97].

2.9. Panax ginseng. Panax ginseng (ginseng) is widely used as a medicinal herb. It has various beneficial activities such as antihypertensive, antifatigue, antioxidative, hypolipidemic, immunoenhancing, and chemopreventive effects [6]. It is the 5th best-selling herb in the United States [98]. The major pharmacologically active components of ginseng are ginsenosides (triterpenoid dammarane saponins) [28]. There are approximately 12 different types of ginsenosides identified [33]. The recommended dose of ginseng is $200 \mathrm{mg} /$ day of standardized extract containing $4 \%$ total ginsenosides [1]. The effect of ginseng and its main active components on the expression and activity of CYP and P-gp is listed in Table 5. In rats, ginseng extract inhibited the in vitro activity of CYP1A1/2, 1B1, and 2E1 in rat liver microsomes [83], while it did not affect the mRNA expression of rat hepatic CYP1A2,
2B1, and 3A23 [84]. Moreover, ginseng extract inhibited CYP1A1, 1A2, and 1B1 activities in recombinant human CYP isozyme system [85]. Ginsenoside Rd weakly inhibited CYP2C9, 2C19, 2D6, and 3A4 activities, while ginsenosides $\mathrm{Rc}$ and Rf increased CYP2C9 and 3A4 activities in recombinant human CYP isozyme system [86]. Ginsenoside Rg3 inhibited P-gp-mediated efflux in multidrug-resistant human fibroblast carcinoma KBV20C cells possibly by decreasing membrane fluidity [87].

\section{Conclusions}

The modulations of CYP and P-gp by ten herbs and relevant phytochemicals have been comprehensively reviewed. Evidences from in vitro and in vivo studies have indicated that herbs can interact with CYP isoforms and P-gp as inhibitors and/or inducers. Since the herbal modulation of CYP and P-gp may have significant clinical and toxicological implications, rigorous evaluation for the possibility of herb-drug interactions may be required in the development process of 
herbal medicines. Efforts to facilitate communications among patients and clinicians regarding a clinical risk of herbdrug interactions are also encouraged [28, 99]. Continuous improvements in our understanding on herb-drug interactions and their pharmacokinetic mechanisms will enable us to better predict, evaluate, and manage potential risks associated with a concurrent use of herb and drug-based therapies.

\section{Conflict of Interests}

The authors declare that there is no conflict of interests regarding the publication of this paper.

\section{Acknowledgments}

This paper was supported by Research Funds of Mokpo National University in 2013. The authors thank Suk-Bum $\mathrm{Kim}, \mathrm{Su}-\mathrm{Mi} \mathrm{Oh}$, and Seong-Eun Jang for technical assistance.

\section{References}

[1] R. Hermann and O. von Richter, "Clinical evidence of herbal drugs as perpetrators of pharmacokinetic drug interactions," Planta Medica, vol. 78, no. 13, pp. 1458-1477, 2012.

[2] M. de Lima Toccafondo Vieira and S.-M. Huang, "Botanicaldrug interactions: a scientific perspective," Planta Medica, vol. 78, no. 13, pp. 1400-1415, 2012.

[3] S. Bent, "Herbal medicine in the United States: review of efficacy, safety, and regulation: grand rounds at University of California, San Francisco Medical Center," Journal of General Internal Medicine, vol. 23, no. 6, pp. 854-859, 2008.

[4] A. Bardia, N. L. Nisly, M. B. Zimmerman, B. M. Gryzlak, and R. B. Wallace, "Use of herbs among adults based on evidencebased indications: Findings from the National Health Interview Survey," Mayo Clinic Proceedings, vol. 82, no. 5, pp. 561-566, 2007.

[5] S.-B. Kim, I.-S. Yoon, K.-S. Kim et al., "In vitro and in vivo evaluation of the effect of puerarin on hepatic cytochrome P450mediated drug metabolism," Planta Medica, vol. 80, no. 7, pp. 561-567, 2014.

[6] S. Zhou, Y. Gao, W. Jiang, M. Huang, A. Xu, and J. W. Paxton, "Interactions of herbs with cytochrome P450," Drug Metabolism Reviews, vol. 35, no. 1, pp. 35-98, 2003.

[7] O. Pelkonen, M. Turpeinen, J. Hakkola, P. Honkakoski, J. Hukkanen, and H. Raunio, "Inhibition and induction of human cytochrome P450 enzymes: current status," Archives of Toxicology, vol. 82, no. 10, pp. 667-715, 2008.

[8] J.-J. Wu, C.-Z. Ai, Y. Liu et al., "Interactions between phytochemicals from traditional Chinese medicines and human cytochrome P450 enzymes," Current Drug Metabolism, vol. 13, no. 5, pp. 599-614, 2012.

[9] A. H. Schinkel and J. W. Jonker, "Mammalian drug efflux transporters of the ATP binding cassette (ABC) family: an overview," Advanced Drug Delivery Reviews, vol. 55, no. 1, pp. 3-29, 2003.

[10] S. Zhou, L. Y. Lim, and B. Chowbay, "Herbal modulation of Pglycoprotein," Drug Metabolism Reviews, vol. 36, no. 1, pp. 57104, 2004.

[11] International Transporter Consortium, K. M. Giacomini, S. M. Huang et al., "Membrane transporters in drug development," Nature Reviews Drug Discovery, vol. 9, no. 3, pp. 215-236, 2010.
[12] J.-E. Kim, I.-S. Yoon, H.-J. Cho, D.-H. Kim, Y.-H. Choi, and D.-D. Kim, "Emulsion-based colloidal nanosystems for oral delivery of doxorubicin: improved intestinal paracellular absorption and alleviated cardiotoxicity," International Journal of Pharmaceutics, vol. 464, no. 1-2, pp. 117-126, 2014.

[13] J.-E. Kim, H.-J. Cho, J. S. Kim et al., “The limited intestinal absorption via paracellular pathway is responsible for the low oral bioavailability of doxorubicin," Xenobiotica, vol. 43, no. 7, pp. 579-591, 2013.

[14] S. Marchetti, R. Mazzanti, J. H. Beijnen, and J. H. M. Schellens, "Concise review: clinical relevance of drug-drug and herb-drug interactions mediated by the ABC transporter ABCB1 (MDR1, P-glycoprotein)," Oncologist, vol. 12, no. 8, pp. 927-941, 2007.

[15] F. V. DeFeudis and K. Drieu, "Ginkgo biloba extract (EGb 761) and CNS functions: basic studies and clinical applications," Current Drug Targets, vol. 1, no. 1, pp. 25-58, 2000.

[16] D. J. McKenna, K. Jones, and K. Hughes, "Efficacy, safety, and use of ginkgo biloga in clinical and preclinical applications," Alternative Therapies in Health and Medicine, vol. 7, no. 5, pp. 70-86, 88-90, 2001.

[17] Y. Tang, F. Lou, J. Wang, Y. Li, and S. Zhuang, "Coumaroyl flavonol glycosides from the leaves of Ginkgo biloba," Phytochemistry, vol. 58, no. 8, pp. 1251-1256, 2001.

[18] K. Shinozuka, K. Umegaki, Y. Kubota et al., "Feeding of Ginkgo biloba extract (GBE) enhances gene expression of hepatic cytochrome P-450 and attenuates the hypotensive effect of nicardipine in rats," Life Sciences, vol. 70, no. 23, pp. 2783-2792, 2002.

[19] J. Tang, J. Sun, Y. Zhang, L. Li, F. Cui, and Z. He, "Herb-drug interactions: effect of Ginkgo biloba extract on the pharmacokinetics of theophylline in rats," Food and Chemical Toxicology, vol. 45, no. 12, pp. 2441-2445, 2007.

[20] C. Gaudineau, R. Beckerman, S. Welbourn, and K. Auclair, "Inhibition of human P450 enzymes by multiple constituents of the Ginkgo biloba extract," Biochemical and Biophysical Research Communications, vol. 318, no. 4, pp. 1072-1078, 2004.

[21] S. M. Robertson, R. T. Davey, J. Voell, E. Formentini, R. M. Alfaro, and S. R. Penzak, "Effect of Ginkgo biloba extract on lopinavir, midazolam and fexofenadine pharmacokinetics in healthy subjects," Current Medical Research and Opinion, vol. 24, no. 2, pp. 591-599, 2008.

[22] B. H. Hellum and O. G. Nilsen, "In vitro inhibition of CYP3A4 metabolism and P-glycoprotein-mediated transport by trade herbal products," Basic and Clinical Pharmacology \& Toxicology, vol. 102, no. 5, pp. 466-475, 2008.

[23] L. Fan, G.-Y. Tao, G. Wang et al., "Effects of Ginkgo biloba extract ingestion on the pharmacokinetics of talinolol in healthy Chinese volunteers," Annals of Pharmacotherapy, vol. 43, no. 5, pp. 944-949, 2009.

[24] L. L. von Moltke, J. L. Weemhoff, E. Bedir et al., "Inhibition of human cytochromes P450 by components of Ginkgo biloba," Journal of Pharmacy and Pharmacology, vol. 56, no. 8, pp. 10391044, 2004.

[25] Y.-H. Liu, S.-L. Mo, H.-C. Bi et al., "Regulation of human pregnane $\mathrm{X}$ receptor and its target gene cytochrome P450 3A4 by Chinese herbal compounds and a molecular docking study," Xenobiotica, vol. 41, no. 4, pp. 259-280, 2011.

[26] K. Rahman, "Historical perspective on garlic and cardiovascular disease," The Journal of Nutrition, vol. 131, supplement 3, pp. 977S-979S, 2001. 
[27] B. S. Joshi and P. N. Kaul, "Alternative medicine: herbal drugs and their critical appraisal part I," Progress in Drug Research, vol. 56, pp. 1-76, 2001.

[28] C. Colalto, "Herbal interactions on absorption of drugs: mechanisms of action and clinical risk assessment," Pharmacological Research, vol. 62, no. 3, pp. 207-227, 2010.

[29] H. Amagase, B. L. Petesch, H. Matsuura, S. Kasuga, and Y. Itakura, "Intake of garlic and its bioactive components," The Journal of Nutrition, vol. 131, no. 3, pp. 955S-962S, 2001.

[30] R. Kishimoto, M. Ueda, H. Yoshinaga, K. Goda, and S.-S. Park, "Combined effects of ethanol and garlic on hepatic ethanol metabolism in mice," Journal of Nutritional Science and Vitaminology, vol. 45, no. 3, pp. 275-286, 1999.

[31] B. C. Foster, M. S. Foster, S. Vandenhoek et al., "An in vitro evaluation of human cytochrome P450 3A4 and P-glycoprotein inhibition by garlic," Journal of Pharmacy and Pharmaceutical Sciences, vol. 4, no. 2, pp. 176-184, 2001.

[32] L. S. Lee, A. S. A. Andrade, and C. Flexner, "Interactions between natural health products and antiretroviral drugs: pharmacokinetic and pharmacodynamic effects," Clinical Infectious Diseases, vol. 43, no. 8, pp. 1052-1059, 2006.

[33] Y. H. Choi, Y.-W. Chin, and Y. G. Kim, "Herb-drug interactions: focus on metabolic enzymes and transporters," Archives of Pharmacal Research, vol. 34, no. 11, pp. 1843-1863, 2011.

[34] M. L. Dupuis, M. Flego, A. Molinari, and M. Cianfriglia, "Saquinavir induces stable and functional expression of the multidrug transporter P-glycoprotein in human CD4 T-lymphoblastoid CEM ${ }^{\text {rev }}$ cells," HIV Medicine, vol. 4, no. 4, pp. 338-345, 2003.

[35] L. Jin and T. A. Baillie, "Metabolism of the chemoprotective agent diallyl sulfide to glutathione conjugates in rats," Chemical Research in Toxicology, vol. 10, no. 3, pp. 318-327, 1997.

[36] C. Teyssier, L. Guenot, M. Suschetet, and M.-H. Siess, "Metabolism of diallyl disulfide by human liver microsomal cytochromes P- 450 and flavin-containing monooxygenases," Drug Metabolism and Disposition, vol. 27, no. 7, pp. 835-841, 1999.

[37] C. Y. Yang, P. D. L. Chao, Y. C. Hou, S. Y. Tsai, K. C. Wen, and S. L. Hsiu, "Marked decrease of cyclosporin bioavailability caused by coadministration of ginkgo and onion in rats," Food and Chemical Toxicology, vol. 44, no. 9, pp. 1572-1578, 2006.

[38] D. Saleheen, S. A. Ali, and M. M. Yasinzai, "Antileishmanial activity of aqueous onion extract in vitro," Fitoterapia, vol. 75, no. 1, pp. 9-13, 2004.

[39] K. E. Campos, Y. S. Diniz, A. C. Cataneo, L. A. Faine, M. J. Q. F. Alves, and E. L. B. Novelli, "Hypoglycaemic and antioxidant effects of onion, Allium cepa: dietary onion addition, antioxidant activity and hypoglycaemic effects on diabetic rats," International Journal of Food Sciences and Nutrition, vol. 54, no. 3, pp. 241-246, 2003.

[40] J. Patel, B. Buddha, S. Dey, D. Pal, and A. K. Mitra, "In vitro interaction of the HIV protease inhibitor ritonavir with herbal constituents: changes in P-gp and CYP3A4 activity," American Journal of Therapeutics, vol. 11, no. 4, pp. 262-277, 2004.

[41] P. P. Maliakal, P. F. Coville, and S. Wanwimolruk, “Tea consumption modulates hepatic drug metabolizing enzymes in Wistar rats," Journal of Pharmacy and Pharmacology, vol. 53, no. 4, pp. 569-577, 2001.

[42] A. Bu-Abbas, M. N. Clifford, R. Walker, and C. Ioannides, "Modulation of hepatic cytochrome P450 activity and carcinogen bioactivation by black and decaffeinated black tea," Environmental Toxicology and Pharmacology, vol. 7, no. 1, pp. 41-47, 1999.
[43] M. Nishikawa, N. Ariyoshi, A. Kotani et al., "Effects of continuous ingestion of green tea or grape seed extracts on the pharmacokinetics of midazolam," Drug Metabolism and Pharmacokinetics, vol. 19, no. 4, pp. 280-289, 2004.

[44] M. I. Netsch, H. Gutmann, C. B. Schmidlin, C. Aydogan, and J. Drewe, "Induction of CYP1A by green tea extract in human intestinal cell lines," Planta Medica, vol. 72, no. 6, pp. 514-520, 2006.

[45] J. Jodoin, M. Demeule, and R. Béliveau, "Inhibition of the multidrug resistance P-glycoprotein activity by green tea polyphenols," Biochimica et Biophysica Acta, vol. 1542, no. 1-3, pp. 149159, 2002.

[46] Y. Mei, F. Qian, D. Wei, and J. Liu, "Reversal of cancer multidrug resistance by green tea polyphenols," The Journal of Pharmacy and Pharmacology, vol. 56, no. 10, pp. 1307-1314, 2004.

[47] D. A. Balentine, S. A. Wiseman, and L. C. M. Bouwens, "The chemistry of tea flavonoids," Critical Reviews in Food Science and Nutrition, vol. 37, no. 8, pp. 693-704, 1997.

[48] J. D. Lambert and C. S. Yang, "Cancer chemopreventive activity and bioavailability of tea and tea polyphenols," Mutation Research, vol. 523-524, pp. 201-208, 2003.

[49] M. Antonello, D. Montemurro, M. Bolognesi et al., "Prevention of hypertension, cardiovascular damage and endothelial dysfunction with green tea extracts," The American Journal of Hypertension, vol. 20, no. 12, pp. 1321-1328, 2007.

[50] I. Papparella, G. Ceolotto, D. Montemurro et al., "Green tea attenuates angiotensin II-induced cardiac hypertrophy in rats by modulating reactive oxygen species production and the Src/epidermal growth factor receptor/Akt signaling pathway," The Journal of Nutrition, vol. 138, no. 9, pp. 1596-1601, 2008.

[51] Y.-W. Chin, H.-A. Jung, Y. Liu et al., "Anti-oxidant constituents of the roots and stolons of licorice (Glycyrrhiza glabra)," Journal of Agricultural and Food Chemistry, vol. 55, no. 12, pp. 46914697, 2007.

[52] M. N. Asl and H. Hosseinzadeh, "Review of pharmacological effects of Glycyrrhiza sp. and its bioactive compounds," Phytotherapy Research, vol. 22, no. 6, pp. 709-724, 2008.

[53] Y. Fujisawa, M. Sakamoto, M. Matsushita, T. Fujita, and K. Nishioka, "Glycyrrhizin inhibits the lytic pathway of complementpossible mechanism of its anti-inflammatory effect on liver cells in viral hepatitis," Microbiology and Immunology, vol. 44, no. 9, pp. 799-804, 2000.

[54] M. Paolini, L. Pozzetti, A. Sapone, and G. Cantelli-Forti, "Effect of licorice and glycyrrhizin on murine liver CYP-dependent monooxygenases," Life Sciences, vol. 62, no. 6, pp. 571-582, 1998.

[55] J.-H. Tu, Y.-J. He, Y. Chen et al., "Effect of glycyrrhizin on the activity of CYP3A enzyme in humans," European Journal of Clinical Pharmacology, vol. 66, no. 8, pp. 805-810, 2010.

[56] T. Nabekura, T. Yamaki, K. Ueno, and S. Kitagawa, "Inhibition of P-glycoprotein and multidrug resistance protein 1 by dietary phytochemicals," Cancer Chemotherapy and Pharmacology, vol. 62, no. 5, pp. 867-873, 2008.

[57] F. Borrelli, R. Capasso, A. Pinto, and A. A. Izzo, "Inhibitory effect of ginger (Zingiber officinale) on rat ileal motility in vitro," Life Sciences, vol. 74, no. 23, pp. 2889-2896, 2004.

[58] M. N. Ghayur and A. H. Gilani, "Pharmacological basis for the medicinal use of ginger in gastrointestinal disorders," Digestive Diseases and Sciences, vol. 50, no. 10, pp. 1889-1897, 2005.

[59] A. S. El-Sharaky, A. A. Newairy, M. A. Kamel, and S. M. Eweda, "Protective effect of ginger extract against bromobenzeneinduced hepatotoxicity in male rats," Food and Chemical Toxicology, vol. 47, no. 7, pp. 1584-1590, 2009. 
[60] B. H. Ali, G. Blunden, M. O. Tanira, and A. Nemmar, "Some phytochemical, pharmacological and toxicological properties of ginger (Zingiber officinale Roscoe): a review of recent research," Food and Chemical Toxicology, vol. 46, no. 2, pp. 409-420, 2008.

[61] Y. Kimura, H. Ito, and T. Hatano, "Effects of mace and nutmeg on human cytochrome P450 3A4 and 2C9 activity," Biological \& Pharmaceutical Bulletin, vol. 33, no. 12, pp. 1977-1982, 2010.

[62] I. S. Kim, S. Y. Kim, and H. H. Yoo, "Effects of an aqueousethanolic extract of ginger on cytochrome P450 enzymemediated drug metabolism," Pharmazie, vol. 67, no. 12, pp. 10071009, 2012.

[63] T. Nabekura, S. Kamiyama, and S. Kitagawa, "Effects of dietary chemopreventive phytochemicals on P-glycoprotein function," Biochemical and Biophysical Research Communications, vol. 327, no. 3, pp. 866-870, 2005.

[64] S. Pandit, P. K. Mukherjee, K. Mukherjee et al., "Cytochrome P450 inhibitory potential of selected Indian spices-possible food drug interaction," Food Research International, vol. 45, no. 1, pp. 69-74, 2012.

[65] K. Srinivasan, "Black pepper and its pungent principle-piperine: a review of diverse physiological effects," Critical Reviews in Food Science and Nutrition, vol. 47, no. 8, pp. 735-748, 2007.

[66] S. Bajad, K. L. Bedi, A. K. Singla, and R. K. Johri, "Antidiarrhoeal activity of piperine in mice," Planta Medica, vol. 67, no. 3, pp. 284-287, 2001.

[67] Y.-F. Bai and H. Xu, "Protective action of piperine against experimental gastric ulcer," Acta Pharmacologica Sinica, vol. 21, no. 4, pp. 357-359, 2000.

[68] J. R. Stöhr, P.-G. Xiao, and R. Bauer, "Constituents of Chinese Piper species and their inhibitory activity on prostaglandin and leukotriene biosynthesis in vitro," Journal of Ethnopharmacology, vol. 75, no. 2-3, pp. 133-139, 2001.

[69] R. Mittal and R. L. Gupta, "In vitro antioxidant activity of piperine," Methods and Findings in Experimental and Clinical Pharmacology, vol. 22, no. 5, pp. 271-274, 2000.

[70] Z. Lin, J. R. S. Hoult, D. C. Bennett, and A. Raman, "Stimulation of mouse melanocyte proliferation by Piper nigrum fruit extract and its main alkaloid, piperine," Planta Medica, vol. 65, no. 7, pp. 600-603, 1999.

[71] S. Bajad, K. L. Bedi, A. K. Singla, and R. K. Johri, "Piperine inhibits gastric emptying and gastrointestinal transit in rats and mice," Planta Medica, vol. 67, no. 2, pp. 176-179, 2001.

[72] V. Badmaev, M. Majeed, and E. P. Norkus, "Piperine, an alkaloid derived from black pepper increases serum response of betacarotene during 14-days of oral beta-carotene supplementation," Nutrition Research, vol. 19, no. 3, pp. 381-388, 1999.

[73] V. Badmaev, M. Majeed, and L. Prakash, "Piperine derived from black pepper increases the plasma levels of coenzyme q10 following oral supplementation," The Journal of Nutritional Biochemistry, vol. 11, no. 2, pp. 109-113, 2000.

[74] M. H. Kang, S. M. Won, S. S. Park, S. G. Kim, R. F. Novak, and N. D. Kim, "Piperine effects on the expression of P4502E1, P4502B and P4501A in rat," Xenobiotica, vol. 24, no. 12, pp. 1195-1204, 1994.

[75] R. K. Bhardwaj, H. Glaeser, L. Becquemont, U. Klotz, S. K. Gupta, and M. F. Fromm, "Piperine, a major constituent of black pepper, inhibits human P-glycoprotein and CYP3A4," Journal of Pharmacology and Experimental Therapeutics, vol.302, no. 2, pp. 645-650, 2002.

[76] G. Sancheti and P. K. Goyal, "Modulatory influence of Rosemarinus officinalis on DMBA-induced mouse skin tumorigenesis,"
Asian Pacific Journal of Cancer Prevention, vol. 7, no. 2, pp. 331335, 2006.

[77] S. N. T. Ngo, D. B. Williams, and R. J. Head, "Rosemary and cancer prevention: preclinical perspectives," Critical Reviews in Food Science and Nutrition, vol. 51, no. 10, pp. 946-954, 2011.

[78] P. Debersac, J. M. Heydel, M. J. Amiot et al., "Induction of cytochrome P450 and/or detoxication enzymes by various extracts of rosemary: description of specific patterns," Food and Chemical Toxicology, vol. 39, no. 9, pp. 907-918, 2001.

[79] C. A. Plouzek, H. P. Ciolino, R. Clarke, and G. G. Yeh, "Inhibition of P-glycoprotein activity and reversal of multidrug resistance in vitro by rosemary extract," European Journal of Cancer, vol. 35, no. 10, pp. 1541-1545, 1999.

[80] Y. Liu, T. J. Flynn, M. S. Ferguson, and E. M. Hoagland, "Use of the combination index to determine interactions between plant-derived phenolic acids on hepatotoxicity endpoints in human and rat hepatoma cells," Phytomedicine, vol. 20, no. 5, pp. 461-468, 2013.

[81] Y. Pan, B. A. Abd-Rashid, Z. Ismail et al., "In vitro effects of active constituents and extracts of Orthosiphon stamineus on the activities of three major human cDNA-expressed cytochrome P450 enzymes," Chemico-Biological Interactions, vol. 190, no. 1, pp. 1-8, 2011.

[82] F.-R. Li, Y.-Y. Fu, D.-H. Jiang et al., "Reversal effect of rosmarinic acid on multidrug resistance in SGC7901/Adr cell," Journal of Asian Natural Products Research, vol. 15, no. 3, pp. 276-285, 2013.

[83] H. J. Kim, Y. J. Chun, J. D. Park, S. I. Kim, J. K. Roh, and T. C. Jeong, "Protection of rat liver microsomes against carbon tetrachloride-lnduced lipid peroxidation by red ginseng," Planta Medica, vol. 63, no. 5, pp. 415-418, 1997.

[84] C.-T. Yu, J. Chen, X. W. Teng, V. Tong, and T. K. H. Chang, "Lack of evidence for induction of CYP2B1, CYP3A23, and CYP1A2 gene expression by Panax ginseng and Panax quinquefolius extracts in adult rats and primary cultures of rat hepatocytes," Drug Metabolism and Disposition, vol. 33, no. 1, pp. 19-22, 2005.

[85] T. K. H. Chang, J. Chen, and S. A. Benetton, "In vitro effect of standardized ginseng extracts and individual ginsenosides on the catalytic activity of human CYP1A1, CYP1A2, and CYP1B1," Drug Metabolism and Disposition, vol. 30, no. 4, pp. 378-384, 2002.

[86] G. L. Henderson, M. R. Harkey, M. E. Gershwin, R. M. Hackman, J. S. Stern, and D. M. Stresser, "Effects of ginseng components on c-DNA-expressed cytochrome P450 enzyme catalytic activity," Life Sciences, vol. 65, no. 15, pp. L209-L214, 1999.

[87] H.-Y. Kwon, E.-H. Kim, S.-W. Kim, S.-N. Kim, J.-D. Park, and D.-K. Rhee, "Selective toxicity of ginsenoside $\mathrm{Rg}_{3}$ on multidrug resistant cells by membrane fluidity modulation," Archives of Pharmacal Research, vol. 31, no. 2, pp. 171-177, 2008.

[88] B. B. Aggarwal and B. Sung, "Pharmacological basis for the role of curcumin in chronic diseases: an age-old spice with modern targets," Trends in Pharmacological Sciences, vol. 30, no. 2, pp. 85-94, 2009.

[89] M.-L. Kuo, T.-S. Huang, and J.-K. Lin, "Curcumin, an antioxidant and anti-tumor promoter, induces apoptosis in human leukemia cells," Biochimica et Biophysica Acta: Molecular Basis of Disease, vol. 1317, no. 2, pp. 95-100, 1996.

[90] P. S. Babu and K. Srinivasan, "Hypolipidemic action of curcumin, the active principle of turmeric (Curcuma longa) in streptozotocin induced diabetic rats," Molecular and Cellular Biochemistry, vol. 166, no. 1-2, pp. 169-175, 1997. 
[91] N. Chainani-Wu, "Safety and anti-inflammatory activity of curcumin: a component of tumeric (Curcuma longa)," The Journal of Alternative and Complementary Medicine, vol. 9, no. 1, pp. 161-168, 2003.

[92] B. B. Aggarwal, A. Kumar, and A. C. Bharti, "Anticancer potential of curcumin: preclinical and clinical studies," Anticancer Research, vol. 23, no. 1, pp. 363-398, 2003.

[93] W. Zhang, T. M. C. Tan, and L.-Y. Lim, "Impact of curcumininduced changes in P-glycoprotein and CYP3A expression on the pharmacokinetics of peroral celiprolol and midazolam in rats," Drug Metabolism and Disposition, vol. 35, no. 1, pp. 110115, 2007.

[94] N. Romiti, R. Tongiani, F. Cervelli, and E. Chieli, "Effects of curcumin on P-glycoprotein in primary cultures of rat hepatocytes," Life Sciences, vol. 62, no. 25, pp. 2349-2358, 1998.

[95] C. S. Yang, T. J. Smith, and J.-Y. Hong, "Cytochrome P-450 enzymes as targets for chemoprevention against chemical carcinogenesis and toxicity: opportunities and limitations," Cancer Research, vol. 54, no. 7, supplement, pp. 1982s-1986s, 1994.

[96] X.-L. Hou, K. Takahashi, K. Tanaka et al., "Curcuma drugs and curcumin regulate the expression and function of P-gp in Caco2 cells in completely opposite ways," International Journal of Pharmaceutics, vol. 358, no. 1-2, pp. 224-229, 2008.

[97] X.-L. Hou, K. Takahashi, N. Kinoshita et al., "Possible inhibitory mechanism of Curcuma drugs on CYP3A4 in $1 \alpha, 25$ dihydroxyvitamin $\mathrm{D}_{3}$ treated Caco-2 cells," International Journal of Pharmaceutics, vol. 337, no. 1-2, pp. 169-177, 2007.

[98] P. M. Barnes, B. Bloom, and R. L. Nahin, "Complementary and alternative medicine use among adults and children: United States, 2007," National health statistics reports, no. 12, pp. 1-23, 2008.

[99] P. A. de Smet, "Clinical risk management of herb-drug interactions," British Journal of Clinical Pharmacology, vol. 63, no. 3, pp. 258-267, 2007. 


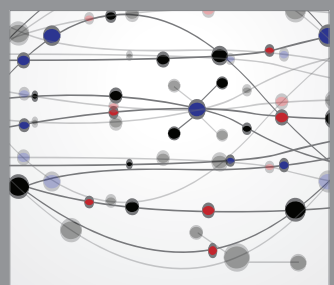

The Scientific World Journal
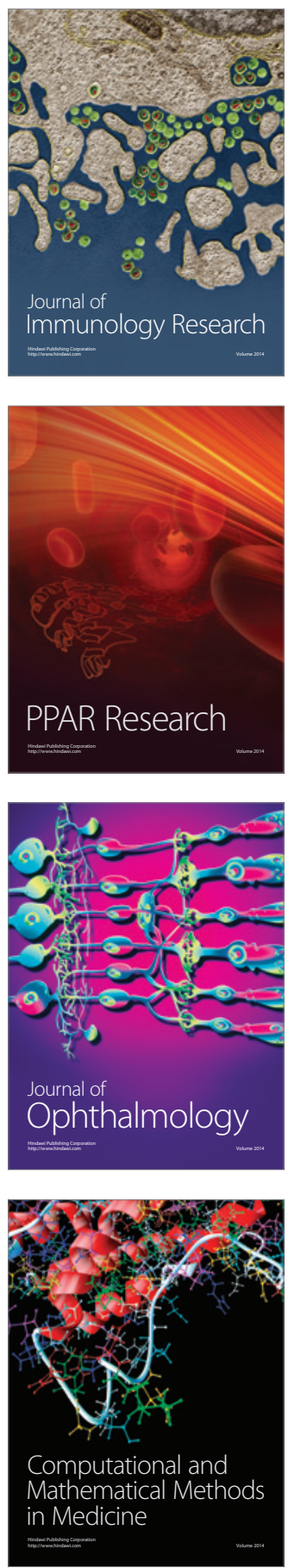

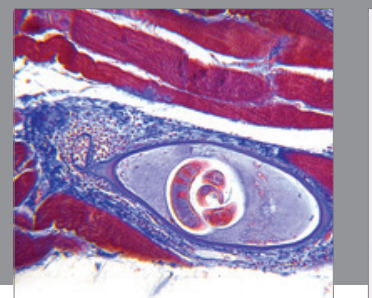

Gastroenterology

Research and Practice
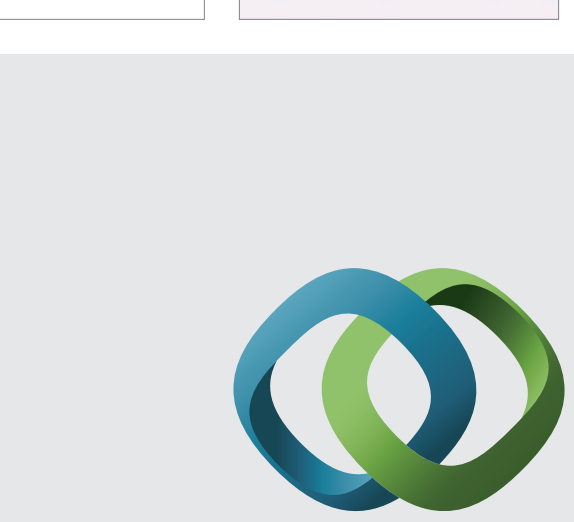

\section{Hindawi}

Submit your manuscripts at

http://www.hindawi.com
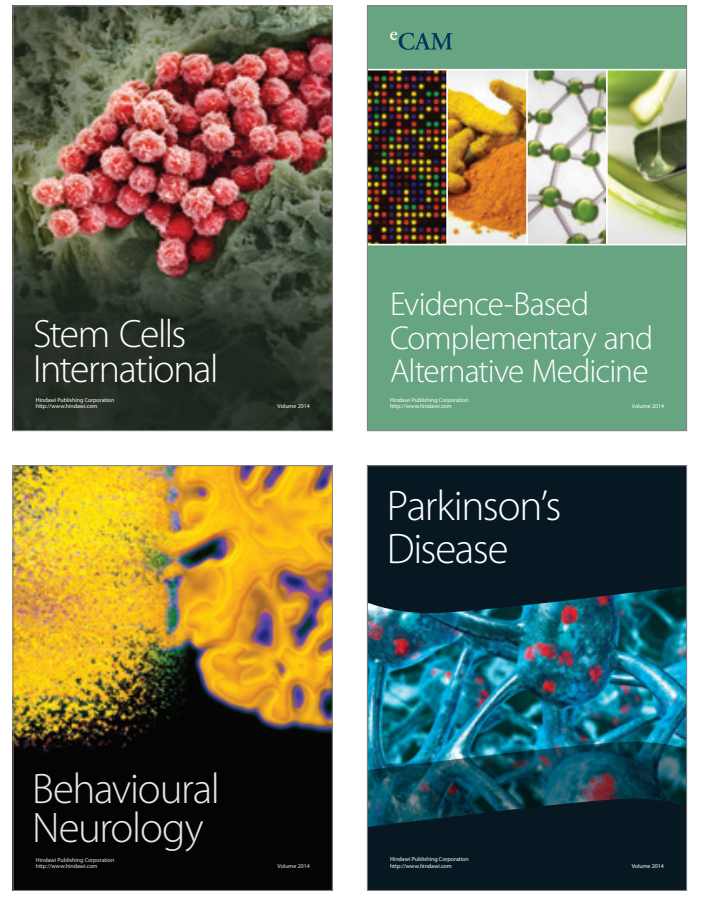
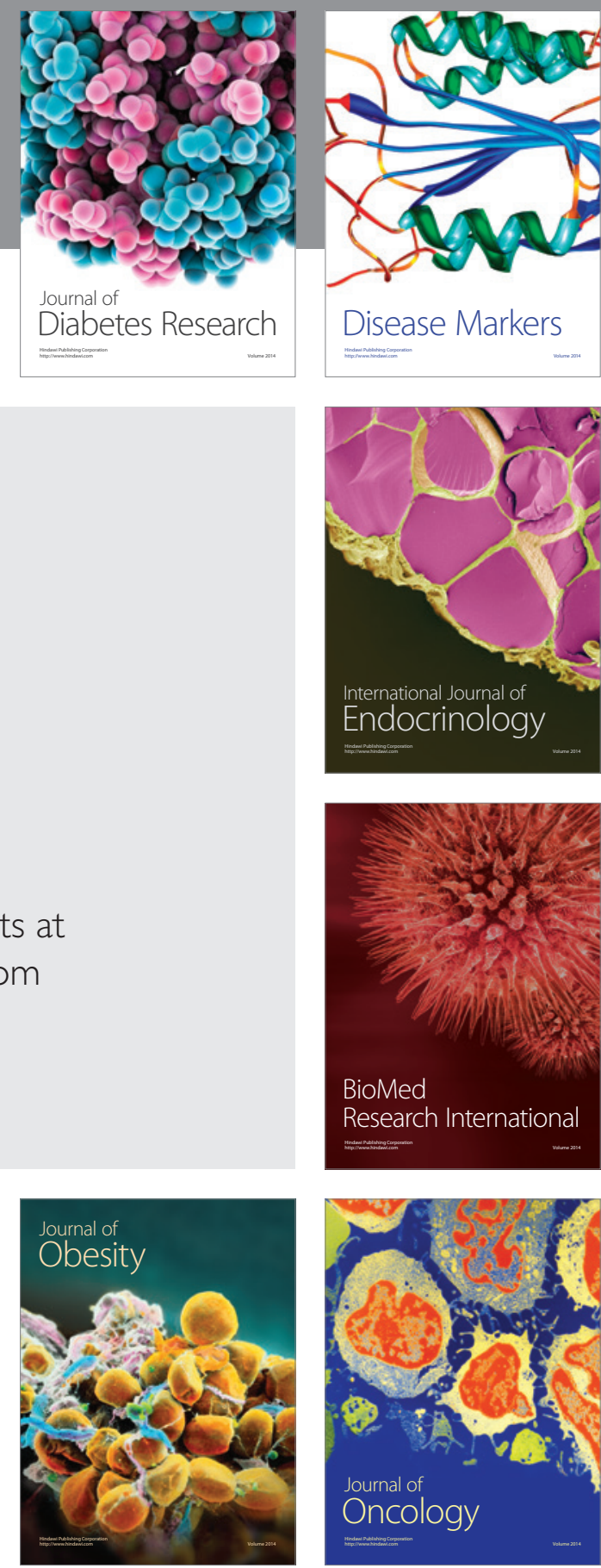

Disease Markers
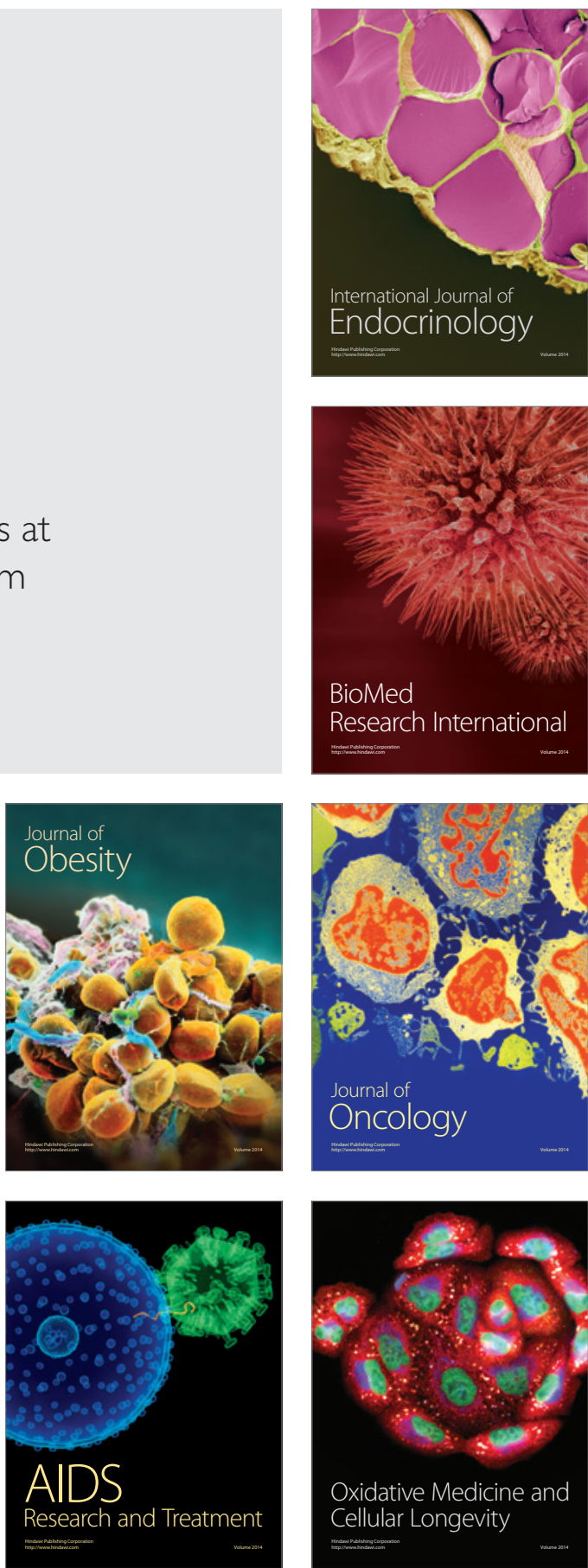